\title{
Conceptualizing Mobile Health Application Use Intention and Adoption Among Iraqian Older Adults: From the Perspective of Expanded Technology Acceptance Model
}

\author{
https://doi.org/10.3991/ijim.v13i10.11285 \\ Murtaja Ali Saare ${ }^{(\varpi)}$, Azham Hussain \\ Universiti Utara Malaysia, Kedah, Malaysia \\ alisaare16@aol.com \\ Wong Seng Yue \\ Universiti Malaya, Kuala Lumpur, Malaysia
}

\begin{abstract}
The aim of this article is to discuss how different factors affect the decision of intention to use and adopt mobile health applications using the extended technology acceptance model (TAM) among older adults in Iraq "Perceived usefulness (PU), perceived ease of use (PEU), subjective norm (SN), and facilitating conditions (FC)" were four key predictors. Gender and age were included as factors for moderating the impact of two key TAM components in the proposed model (PU and PEU) on intention to use and adoption behaviors. The results of the past studies indicated that PU, PEU and SN were important predictors of adoption of mobile health applications among older adults in Iraq, While PU, SN, and FC were important predictors of the intention to use mobile health applications. Previous studies highlighted a strong impact of PEU on the intention to use mobile health applications on older adults than for younger adults. Implications are discussed for future research and practices.
\end{abstract}

Keywords - Mobile health applications adoption, Mobile health applications use intention, Older adults, TAM, Perceived usefulness, perceived ease of use, Subjective norm, Facilitating conditions.

\section{Introduction}

Technological development such as a smartphone has been witnessed in healthcare (Bujnowska-Fedak \& Pirogowicz, 2014). According to World Health Organization, mobile health (mHealth) technology is the use of mobile device into a medical profession. In terms of smartphone ownership, many studies indicate an increase in mobile health adoption as a result of increase in ownership, specifically, among younger adults rather than older adults. Literature found that $18 \%$ of older adults has adopted to smartphone (Anderson \& Perrin, 2017; Smith, 2014). For example, Smartphone penetration rate is $17 \%$ in Iraq (Ameen \& Willis, 2018). However, the age group adopting technology was younger adults.

Pew research Project (Rainie \& Fox, 2012) found that not all age groups accept and use Smartphone, for example, only 18 percent of older adults have adopted 
Smartphone (Anderson \& Perrin, 2017; Saare, Hussain, \& Yue, 2019; Smith, 2014) The possible reason that literature reveals is a significant gap in terms of user interface design requirements (Poushter, 2016). For example, complex structures of the menu cause older adults to experience stress because older adults need to think about what to select for a longer time to select. As cognitive refers to thinking patterns which has declined in older adults due to their age, motor skills are dexterity of their fingers and vision are lost. Moreover, the design of healthcare applications (Saare, Murtaja Ali; Jasim, Osamah Mohammed; Mahdi, Alia Ahmed; Hussain, 2018) in particular is skewed towards younger adults (Grindrod et al., 2018; Kuerbis, Mulliken, Muench, Moore, \& Gardner, 2017a; Petrovčič, Taipale, Rogelj, \& Dolničar, 2018; Tsai, Shillair, \& Cotten, 2017), however, the requirements of older adults are different from those of younger adults (Joshi \& Bråthen, 2016) because they experience age related decline in cognition (Chin et al., 2017). Nevertheless, the specific requirements of older adults did not meet their needs as they are poorly captured (Young, Koppel, \& Charlton, 2016).

Digital divide has become an important issue of concern in various developing countries as the health issues could be overcome through technology (Hussain, Saare, Jasim, \& Mahdi, 2018) as technology has proved to be beneficial by providing economical technological solutions that reduce the economic burden of a patient's disease (Bastawrous \& Armstrong, 2013). Smart phones are one of the most important mobile devices in modern life that have played an increasingly important role in health care. Many studies have shown that m-health has developed to support diseases and are convenient (Ameen \& Willis, 2018). Moreover, there is a gap found in term of $\mathrm{m}$ health applications adoption as older adult reached over 50 years old is found to be considerably less adopters than their younger counterparts (Boulos, Wheeler, Tavares, \& Jones, 2011).

The aim of this study is to identify different factors influencing the intention to use and adopt mobile health among Iraqi older adults. As the population of older adults is continuously increasing therefore, it is important to capture the needs of this growing population. The present study considers expanding technology acceptance model which is an improvement of the original technology acceptance model (TAM). The TAM has become most popular model that many researchers used to examine technology adoption and it was originated from the reasoned action theory (Ajzen \& Fishbein, 1975). Moreover, the factors that determine the adoption and intention of $\mathrm{m}$ health by elderly people should be clearly examine and understood rather than looking at the techniques of adoption. The physical design aspects of the technology as well as the societal status need to be considered in making technology adoption decisions (see figure 1). For instance, social status of individuals and experiences could determine whether to support the technology or not. The four key predictors of TAM are: "Perceived usefulness", "perceived ease of use", "subjective norm", and "facilitating conditions". In our proposed framework, moderating factors such as gender and age have been included for perceived usefulness and perceived ease of use on use intention and adoption behaviour (see Figure 1).

This study has an empirical and theoretically significant contribution to aging and technology studies. First of all, the TAM model was used to investigate the adoption 
of m-health among the elderly in Iraq, which was not widely studied in the literature. Secondly, it added two factors, "subjective norm" and "facilitating conditions", to the TAM model, so that we can understand better of how m-health adoption among older adults in Iraq is affected by subjective norm, and by certain environmental. For example, lack of access to mobile health, training of staffs and users as well as technical support from third party. Thirdly, notable variation in mobile heath adoption with the elderly as a diverse group have been noticed (Phongtankuel et al., 2018; Vesel, Hipgrave, Dowden, \& Kariuki, 2015). The study contributed to this knowledge by examining whether TAM factors effect of on the adoption and intention to use $\mathrm{m}$ health application can be moderated by the older adults ' age and gender. The results of the study will have an impact for those who want to promote m-health application among Iraqian older adults.

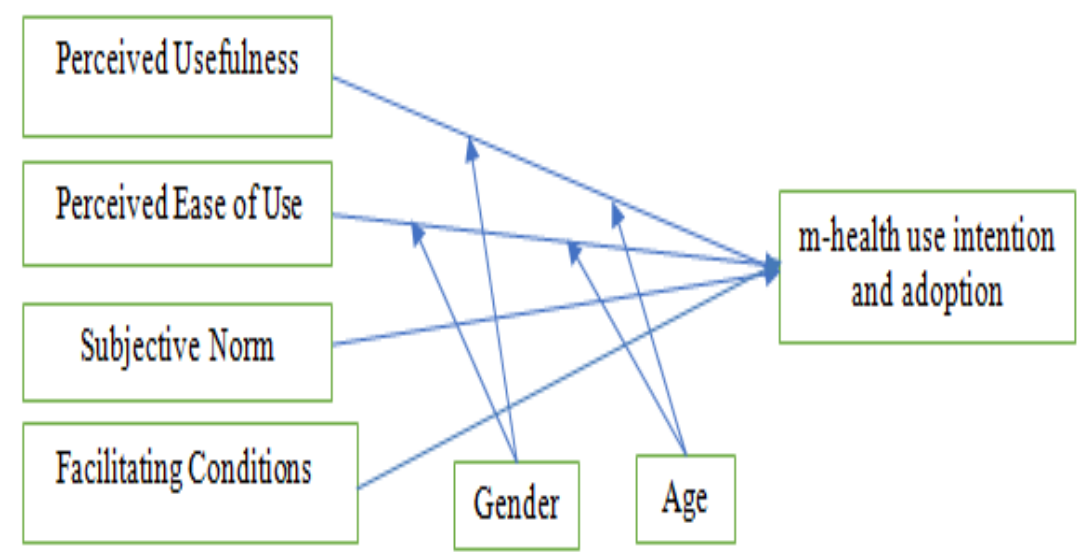

Fig. 1. The influence of perceived usefulness, perceived ease of use, subjective norm, and facilitating conditions on intention and adoption of $\mathrm{m}$-health application and the moderating role of gender and age

\section{$2 \quad$ Literature Review}

\section{$2.1 \quad$ Technology acceptance model}

Some basic and Important human behaviour theories derived from Social psychology has suggested the adoption and use of new technologies by individuals, including the theory of diffusion (Rogers, 1995) as well as reasoned action (Ajzen \& Fishbein, 1975) and social cognitive (Bandura, 1986) with planned behaviour (Ajzen, 1991). This study used the most widely use model among researchers Davis, (1989) suggests that technology can be used to determine behavioural intention, which is impacted by two key beliefs, "perceived usefulness and perceived ease of use". Perceived usefulness is defined as "the extent to which a person believes that using a particular technology will enhance her/his job performance" (p. 320). It has been defined perceived 
ease of use as "the degree to which a person believes that using a technology will be free from effort" (p. 320). Many research has shown that PU and PEOU can significantly predict the intention and behavior of the user with new technology such as a Smartphone (Saare, Sa, Lashari, \& Sari, 2018), Internet (Kuerbis, Mulliken, Muench, Moore, \& Gardner, 2017b), instant messaging (Lu, Zhou, \& Wang, 2009), telemedicine (Dwivedi, Rana, Jeyaraj, Clement, \& Williams, 2017), e-mail (Gastaldi, Segato, Radaelli, Lettieri, \& Corso, 2017), PDA (Arning \& Ziefle, 2007), mobile banking (Abbas et al., 2018), and m-health (Kalimullah \& Sushmitha, 2017). Some factors may be included. To test the assumption, the work suggested these hypotheses:

- H1a. The perceived usefulness will have a positive impact on the intention of using m-health.

- H1b. The perceived usefulness will have a positive impact on the adoption of mhealth.

- H2a. The perceived ease of use has a positive impact on the intention to use mhealth.

- H2b. The Perceived ease of use will have a positive effect on the adoption of mhealth.

\subsection{The expanded TAM model}

TAM parsimony is the most powerful model for predicting the acceptance of technology in different situations. However, the limitation of original TAM 's parsimony cannot be exaggerating due to it difficulty in providing enough information to understand the behaviour of adoption. To examine the theoretical models of technology acceptance, Venkatesh, Morris, Davis, \& Davis, (2003) investigated 8 theoretical models that are widely used in the acceptance of technology. The significance of the addition two additional direct determinants to the TAM "social influence and facilitating conditions". These two important constructs are potentially crucial to understand the acceptance of the user, as almost all play a crucial role in determining how new technologies are adopted by users.

\subsection{Subjective norm}

Many definitions were provided for subjective norms but the most acceptable one included theory in term of reasoned actions (Ajzen \& Fishbein, 1975) and behaviour (Ajzen, 1991). This study considered subjective norms rather to build the research model, as subjective norms are commonly referred to in the research papers. In addition to that, some definitions were given to subjective norm in term of perceptions and the user behaviour (Ajzen \& Fishbein, 1975, p. 302). This concept highlights the social influence capacity in determining the behavior of people. Many researchers have found subjective norm have as direct and positive influence on intention and adoption behaviours. (Hsu \& Lu, 2004; Karahanna, Straub, \& Chervany, 1999; Tarhini, Hone, Liu, \& Tarhini, 2017). Therefore, the research suggested the following hypotheses: 
- H3a. Subjective norm will have a positive impact on the intention to use m-health.

- H3b. Subjective norm will have a positive impact on the adoption of m-health.

\subsection{Facilitating conditions}

Facilitating conditions refers to how a person believes that its use of the information system would support an existing technical infrastructure (Tams, Grover, \& Thatcher, 2014). Thompson, Higgins, \& Howell, (1991) present some factors affecting acceptance and use of technology. They revealed in their study the effect of facilitating the use of computers 1994. However, lack of attempts to investigate the effect of potential factors that act as a barrier among older adults in adoption of m-health (Cook et al., 2017; Hoque, Bao, \& Sorwar, 2017; Stellefson et al., 2017; Zhao, Ni, \& Zhou, 2017). It was found that many older adults recently complained that they choose to adopt Smartphone if they offered relevant classes more conveniently (Choudrie, Pheeraphuttharangkoon, \& Ojiako, 2017). Another prohibitive factor has been found to be financial costs (Macedo, 2017). In addition, Very few technological applications have been developed on the market for older users. (Fischer, David, Crotty, Dierks, \& Safran, 2014). In general, the perception of older adults about advance state of technical assistance, specifically access, costs, and the availability significantly influences $\mathrm{m}$ - health usage intention and later adoption. However,the effect of these advance states in research into the use of $\mathrm{m}$ - health was generally overlooked. This led to the formulation of the following hypotheses:

- H4a. Facilitating conditions will have a positive influence on the intention to use m-health.

- H4b. Facilitating conditions will have a positive influence on adoption of m-he.

\subsection{The moderating effect of gender and age}

Venkatesh et al., (2003) studied the effect of PEOU and PU for technology use and adoption also discussed gender and age as moderating factors. This studied lead to the development of United Theory of Acceptance and Use of Technology model (UTAUT).

\subsection{Gender}

Gender form a major factor contributing the adoption and intention to use technology. Previous studies have found that males are more positive and less concerned about technological innovations (Suki, 2011). Cai, Fan, \& Du, (2017) found that men perceived e-learning system useful and easy to use. Furthermore, studies have shown that instrumental factors such as usefulness motivate men whereas, process factors such as the PEOU for technology adoption (Liu, 2017; Teo \& Milutinovic, 2015) can easily influence women.

In the context of Arab countries, previous evidence has highlighted the difference in gender in the adoption of smartphones (Rhema, 2013) due to cultural differences 
(Yasin, Alavi, Czuchry, \& Shafieyoun, 2014). Gender difference are crucial to discuss as Arab women face cultural restrictions in the adoption of mobile phones (Ameen \& Willis, 2016). Moreover, found gender to be a significant moderating factor that has strong effect on the smartphone technology adoption (Venkatesh, Thong, \& Xu, 2012). Therefore, we have suggested the hypotheses below:

- H5a. The affect of PU on the intention to use m-health application will be stronger for male seniors than for female seniors.

- H5b. The effect of perceived usefulness on adoption m-health will be stronger for male seniors than female seniors.

- H6a. The effect of perceived ease of use on intention to use m-health will be stronger for female seniors than male seniors.

- H6b. The effect of perceived ease of use on adoption m-health will be stronger for female seniors than male seniors.

\subsection{Age}

It has been deduced that young people attach more importance to the extrinsic advantages of technology, such as its usefulness. Ameen \& Willis (2016) found that the perceived usefulness had an impact on intention to use technology among youthful generation was stronger than for elderly generation in Iraq. Consequently, the elderly can be more process-oriented, possible to examine the effort needed to adopt a new emerging technology and more carefully to exploit the risks of these intentions and their benefits. In terms of empirical evidence, studies shown that the physical interrelation among different older people in terms of technology usage were important in achieving maximum usefulness (Arning \& Ziefle, 2007; Venkatesh et al., 2003). Furthermore, below hypotheses were formulated:

- H7a. The effect of perceived usefulness on the intention to use m- health will be stronger for younger adults than older adults.

- H7b. The effect of perceived usefulness on adoption m-health will be stronger for younger adults than older adults.

- H8a. The effect of perceived ease of use on the intention to use m- health will be stronger for older adults than younger adults.

- H8b. The effect of perceived ease of use on adoption m-health will be stronger for older adults than younger adults. 


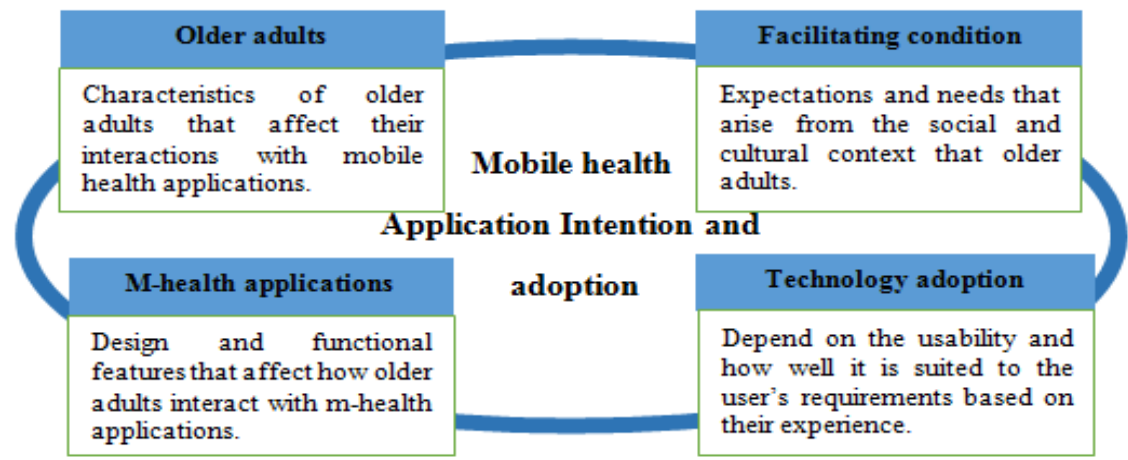

Fig. 2. Four aspects addressed by mobile health intention and adoption factors

\section{Methods}

Various research articles have been reviewed for this study. Some of the indexing searches engines consider for the searches were google scholar, Scopus, and web of science among others using search keywords. Similar studies and related search results included in the references have also been examined. The study investigated other related journals and conferences including book chapters to obtain information. During the early stage of the search review, the research exclude all research papers that not directly focusing on user interaction design related problems. The research also excluded all core technical design papers but included the multi disciplinary aspect of such similar papers, especially on single project.

We focused on the recently published papers and found at least 69 with factor identification within their references published between 2013 and above. The references guided research to obtain relevant results though some researchers criticize on different views but up to now no clearly scientific justification to that claims. Research papers from different field were consulted and review. Such papers came from Gerontological journals, Journal of the American Geriatrics Society, Ageing International, Psychology and Aging, Ageing and Society, and Journal of Applied Gerontology among others. MIS Quarterly, the Emerging Technologies and Society International Journal were such journals considered from information technology field. Business related journals mainly on marketing and operation management were also included. For instance, the research reviewed papers from Journals from marketing research. Furthermore, the research reviewed papers from reputable journals as well as conferences were consulted, and information was retrieved. These papers help to obtain information on human factors as well as design studies. Moreover, medical related journals were not left behind as medical information and the Internet in medicine are significant in mobile health field. The research reviewed theoretical and empirical evidence into the adoption of technology by older adults. Based on the references consulted for medical journals, several studies were outlined to guide our new research. 
Paper-Conceptualizing Mobile Health Application Use Intention and Adoption Among Iraqian Older...

Table 1. Past studies on factors affecting technology adoption and intention to use

\begin{tabular}{|c|c|c|}
\hline Theme & Factor & References \\
\hline \multirow[t]{4}{*}{$\begin{array}{l}\text { Benefits expected of } \\
\text { technology }\end{array}$} & Increased safety & $\begin{array}{l}\text { (Chung, Demiris, \& Thompson, 2016; Peek et al., } \\
\text { 2014) }\end{array}$ \\
\hline & Perceived usefulness & $\begin{array}{l}\text { (Appelboom et al., 2014; Arnhold, Quade, \& } \\
\text { Kirch, 2014) }\end{array}$ \\
\hline & Increased independence & (van Hoof, Kort, Rutten, \& Duijnstee, 2011) \\
\hline & $\begin{array}{l}\text { Reduced burden on family care- } \\
\text { givers }\end{array}$ & (Appelboom et al., 2014; Fischer et al., 2014) \\
\hline \multirow[t]{3}{*}{ Social influence } & Influence of family and friends & (Peek, Aarts, \& Wouters, 2017) \\
\hline & $\begin{array}{l}\text { Influence of professional care- } \\
\text { givers }\end{array}$ & (van Hoof et al., 2011) \\
\hline & Use by peers & $\begin{array}{l}\text { (Alamri et al., 2013; Wilson, Hargreaves, \& } \\
\text { Hauxwell-Baldwin, 2015) }\end{array}$ \\
\hline \multirow[t]{4}{*}{$\begin{array}{l}\text { Characteristics of } \\
\text { older adults }\end{array}$} & Desire to age in place & $\begin{array}{l}\text { (Steggell, Hooker, Bowman, Choun, \& Kim, } \\
\text { 2010; van Hoof et al., 2011) }\end{array}$ \\
\hline & Cultural background & $\begin{array}{l}\text { (Lai, Chung, Leung, Wong, \& Mak, 2010; } \\
\text { Steggell et al., 2010) }\end{array}$ \\
\hline & $\begin{array}{l}\text { Familiarity with electronic tech- } \\
\text { nology }\end{array}$ & $\begin{array}{l}\text { (Courtney, Demeris, Rantz, \& Skubic, 2008; } \\
\text { Steele, Lo, Secombe, \& Wong, 2009) }\end{array}$ \\
\hline & Housing type & (Courtney et al., 2008; Steele et al., 2009) \\
\hline
\end{tabular}

\section{$4 \quad$ Discussion and Conclusion}

Technology is considered as an efficient way to keep older people interactive (Kuerbis et al., 2017a). However, due to absence in the assessment of the lifestyles, needs, and expectations of older adults, m-health applications are not widely used by older adults. In designing, developing, and adopting m-health applications requires careful understanding to avoid any kind of bias (Lee, 2013). Previous studies concentrated mainly on providing the design guidelines that would help application designs to adopt changes whenever needed. However, other features that are mainly important were not considered.

This study reviewed previous literature to understand the intention and adoption of mobile health application among older adults in Iraq. The results indicate that the proposed model can effectively and efficiently help in intention to use and adopt technology based on empirical evidences. It can also address any issues of user interaction with the technology. Furthermore, the research investigated the practical implications of the proposed model utilizing different literatures. These literatures identified 6 factors which gender and age serve as their moderating effect. Each factor plays an important role in mobile health adoption and therefore, the research found them worthwhile to discuss. Moreover, the research adopted TAM model to examine how user intent to use the mobile health and adopt. The results showed how the perceived ease of use within mobile application (Saare, Ta'a, Lashari, \& Sari, 2018) has significant effect as compared to perceive usefulness which is merely important for use of mobile health users such as elderly (Arning \& Ziefle, 2007; Venkatesh et al., 2003). 
Social characteristics among individuals also contributed to the adoption of mobile health and several factors can be included to improve the decision to adopt and use any emerging technology (Saare \& Hussain, 2018). The system design has been also recognised as an important factor for any ergonomics system (Barnes Hofmeister \& Stibe, 2017). Although there is not sufficient discussion on how elderly adults can use mobile health, this provides the needs for further research in the area. In future, integrating our literature findings with other similar but related factors can basically addresses adoption issues.

Moreover, the proposed model can be empirically tested in different contexts that will serve as another direction which needs to be look into and addressed. In addition to that, the relationship between several factors and each factor can connect to improve user interaction with mobile heath application which can also be serving as interesting area to looked into further. Adult, especially elderly ones were complaining about their satisfaction with the technology (Young et al., 2016). Design should not only focus on design for younger adults, but also on the decrease in cognition associated with the age of the older adult. Another possible topic for future studies would therefore be to look more closely at the service side of m-health applications. Most of the previous works concentrated mainly how to improve the design and incorporate some factors that would add values for younger adults. Such factors could be able to achieve the objectives of any interaction design principle. Moreover, such factors must also be useful to older adults on different types of technology been it simple or complex. This is because different categories of technology have interactivity and such the unify design which will improve not only for older adults but all users of mhealth applications.

\section{$5 \quad$ References}

[1] Abbas, S. K., Hassan, H. A., Asif, J., Ahmed, B., Hassan, F., \& Haider, S. S. (2018). Integration of TTF, UTAUT, and ITM for mobile Banking Adoption. International Journal of Advanced Engineering, Management and Science, 4(5). https://doi.org/10.22161/ijaems. $\underline{4.5 .6}$

[2] Ajzen, I. (1991). The theory of planned behavior. Organizational Behavior and Human Decision Processes, 50(2), 179-211. https://doi.org/10.1016/0749-5978(91)90020-t

[3] Ajzen, I., \& Fishbein, M. (1975). Belief, attitude, intention and behavior: An introduction to theory and research. Reading, MA: Addison-Wesley.

[4] Alamri, A., Ansari, W. S., Hassan, M. M., Hossain, M. S., Alelaiwi, A., \& Hossain, M. A. (2013). A survey on sensor-cloud: architecture, applications, and approaches. International Journal of Distributed Sensor Networks, 9(2), 917923.https://doi.org/10.1155/2013/917923

[5] Ameen, N. A., \& Willis, R. (2016). The use of mobile phones to support women's entrepreneurship in the Arab countries. International Journal of Gender and Entrepreneurship, 8(4), 424-445. https://doi.org/10.1108/ijge-10-2015-0037

[6] Ameen, N., \& Willis, R. (2018a). An Examination of the Role of National IT Development and Infrastructure in Models for Smartphone Adoption and Use: The Cases of Iraq, Jordan and the UAE. In Emerging Markets from a Multidisciplinary Perspective (pp. 161-194). Springer. https://doi.org/10.1007/978-3-319-75013-2_14 
[7] Ameen, N., \& Willis, R. (2018b). Towards closing the gender gap in Iraq: understanding gender differences in Smartphone adoption and use. Information Technology for Development, 1-26. https://doi.org/10.1080/02681102.2018.1454877

[8] Anderson, M., \& Perrin, A. (2017). Technology use among seniors. Washington, DC: Pew Research Center for Internet \& Technology.

[9] Appelboom, G., Camacho, E., Abraham, M. E., Bruce, S. S., Dumont, E. L. P., Zacharia, B. E., Bruyère, O. (2014). Smart wearable body sensors for patient self-assessment and monitoring. Archives of Public Health, 72(1), 28. https://doi.org/10.1186/2049-3258-72-28

[10] Arnhold, M., Quade, M., \& Kirch, W. (2014). Mobile applications for diabetics: a systematic review and expert-based usability evaluation considering the special requirements of diabetes patients age 50 years or older. Journal of Medical Internet Research, 16(4). https://doi.org/10.2196/jmir.2968

[11] Arning, K., \& Ziefle, M. (2007). Understanding age differences in PDA acceptance and performance. Computers in Human Behavior, 23(6), 2904-2927. https://doi.org/10.1016/ j.chb.2006.06.005

[12] Bandura, A. (1986). Social foundations of thought and action: A social cognitive theory. Englewood Cliffs, NJ, US: Prentice-Hall, Inc. https://doi.org/10.5465/amr.1987.4306538

[13] Barnes Hofmeister, T., \& Stibe, A. (2017). Living mobility transitions towards bicycling. Designing practices through co-creation and socially influencing systems. The Design Journal, 20(sup1), S3305-S3316. https://doi.org/10.1080/14606925.2017.1352834

[14] Bastawrous, A., \& Armstrong, M. J. (2013). Mobile health use in low-and high-income countries: an overview of the peer-reviewed literature. Journal of the Royal Society of Medicine, 106(4), 130-142. https://doi.org/10.1177/0141076812472620

[15] Boulos, M. N. K., Wheeler, S., Tavares, C., \& Jones, R. (2011). How Smartphone are changing the face of mobile and participatory healthcare: an overview, with example from eCAALYX. Biomedical Engineering Online, 10(1), 24. https://doi.org/10.1186/1475925x-10-24

[16] Bujnowska-Fedak, M. M., \& Pirogowicz, I. (2014). Support for e-health services among elderly primary care patients. Telemedicine and E-Health, 20(8), 696-704. https://doi.org/ $\underline{10.1089 / \mathrm{tmj} .2013 .0318}$

[17] Cai, Z., Fan, X., \& Du, J. (2017). Gender and attitudes toward technology use: A metaanalysis. Computers \& Education, 105, 1-13. https://doi.org/10.1016/j.compedu.2016.11. $\underline{003}$

[18] Chin, J., Madison, A., Gao, X., Graumlich, J. F., Conner-Garcia, T., Murray, M. D., Morrow, D. G. (2017). Cognition and health literacy in older adults' recall of self-care information. The Gerontologist, 57(2), 261-268. https://doi.org/10.1093/geront/gnv091

[19] Choudrie, J., Pheeraphuttharangkoon, S., \& Ojiako, U. (2017). 15 Smartphone Adoption and Usage by 50+ Adults in the United Kingdom. Social Inclusion and Usability of ICTEnabled Services. https://doi.org/10.4324/9781315677316-16

[20] Chung, J., Demiris, G., \& Thompson, H. J. (2016). Ethical considerations regarding the use of smart home technologies for older adults: an integrative review. Annual Review of Nursing Research, 34(1), 155-181. https://doi.org/10.1891/0739-6686.34.155

[21] Cook, E. J., Randhawa, G., Guppy, A., Sharp, C., Barton, G., Bateman, A., \& Crawfordwhite, J. (2017). Exploring factors that impact the decision to use assistive telecare: perspectives of family care-givers of older people in the United Kingdom. Ageing \& Society, 1-21. https://doi.org/10.1017/s0144686x1700037x

[22] Courtney, K. L., Demeris, G., Rantz, M., \& Skubic, M. (2008). Needing smart home technologies: the perspectives of older adults in continuing care retirement communities. https://doi.org/10.14236/jhi.v16i3.694 
[23] Davis, F. D. (1989). Perceived usefulness, perceived ease of use, and user acceptance of information technology. MIS Quarterly, 319-340. https://doi.org/10.2307/249008

[24] Dwivedi, Y. K., Rana, N. P., Jeyaraj, A., Clement, M., \& Williams, M. D. (2017). Reexamining the unified theory of acceptance and use of technology (UTAUT): Towards a revised theoretical model. Information Systems Frontiers, 1-16. https://doi.org/10.1007/ s10796-017-9774-y

[25] Fischer, S. H., David, D., Crotty, B. H., Dierks, M., \& Safran, C. (2014). Acceptance and use of health information technology by community-dwelling elders. International Journal of Medical Informatics, 83(9), 624-635. https://doi.org/10.1016/j.ijmedinf.2014.06.005

[26] Gastaldi, L., Segato, F., Radaelli, G., Lettieri, E., \& Corso, M. (2017). Professionals' Use of IT in Hospitals: Evidence of User Acceptance and Institutional Factors for the EMRs in Italy. In 18th International Continuous Innovation Network (CINet) Conference "Digitalization and Innovation: Designing the Organization of the Future" (pp. 188-201).

[27] Grindrod, K., Khan, H., Hengartner, U., Ong, S., Logan, A. G., Vogel, D., Yang, J. (2018). Evaluating authentication options for mobile health applications in younger and older adults. PloS One, 13(1), e0189048. https://doi.org/10.1371/journal.pone.0189048

[28] Hoque, M. R., Bao, Y., \& Sorwar, G. (2017). Investigating factors influencing the adoption of e-Health in developing countries: A patient's perspective. Informatics for Health and Social Care, 42(1), 1-17. https://doi.org/10.3109/17538157.2015.1075541

[29] Hsu, C.-L., \& Lu, H.-P. (2004). Why do people play on-line games? An extended TAM with social influences and flow experience. Information \& Management, 41(7), 853-868. https://doi.org/10.1016/j.im.2003.08.014

[30] Hussain, A., Saare, M. A., Jasim, O. M., \& Mahdi, A. A. (2018). A Heuristic Evaluation of Iraq E-Portal. Journal of Telecommunication, Electronic and Computer Engineering (JTEC), 10(1-10), 103-107.

[31] Joshi, S. G., \& Bråthen, H. (2016). SUPPORTING NEW INTERACTIONS WITH PAST EXPERIENCES ANCHORED IN MATERIALS. IADIS-INTERNATIONAL JOURNAL ON COMPUTER SCIENCE AND INFORMATION SYSTEMS, 11(2), 74-89.

[32] Kalimullah, K., \& Sushmitha, D. (2017). Influence of Design Elements in Mobile Applications on User Experience of Elderly People. Procedia Computer Science, 113, 352-359. https://doi.org/10.1016/j.procs.2017.08.344 https://doi.org/10.1016/j.procs.2017.08.344

[33] Karahanna, E., Straub, D. W., \& Chervany, N. L. (1999). Information technology adoption across time: a cross-sectional comparison of pre-adoption and post-adoption beliefs. MIS Quarterly, 183-213. https://doi.org/10.2307/249751

[34] Kuerbis, A., Mulliken, A., Muench, F., Moore, A. A., \& Gardner, D. (2017a). Older adults and mobile technology: Factors that enhance and inhibit utilization in the context of behavioral health. https://doi.org/10.31235/osf.io/3qudt

[35] Kuerbis, A., Mulliken, A., Muench, F., Moore, A. A., \& Gardner, D. (2017b). Older adults and mobile technology: Factors that enhance and inhibit utilization in the context of behavioral health. https://doi.org/10.31235/osf.io/3qudt

[36] Lai, C. K. Y., Chung, J. C. C., Leung, N. K. L., Wong, J. C. T., \& Mak, D. P. S. (2010). A survey of older Hong Kong people's perceptions of telecommunication technologies and telecare devices. Journal of Telemedicine and Telecare, 16(8), 441-446. https://doi.org/10. $\underline{1258 / \mathrm{jtt} .2010 .090905}$

[37] Lee, C. (2013). Adoption of smart technology among older adults: Challenges and issues. Public Policy \& Aging Report, 24(1), 14-17. https://doi.org/10.1093/ppar/prt005

[38] Liu, Y. (2017). Gender difference in social media group participation. In E-Learn: World Conference on E-Learning in Corporate, Government, Healthcare, and Higher Education (pp. 709-714). Association for the Advancement of Computing in Education (AACE). 
[39] Lu, Y., Zhou, T., \& Wang, B. (2009). Exploring Chinese users' acceptance of instant messaging using the theory of planned behavior, the technology acceptance model, and the flow theory. Computers in Human Behavior, 25(1), 29-39. https://doi.org/10.1016/j.chb. 2008.06.002

[40] M. Yasin, M., Alavi, J., Czuchry, A., \& Shafieyoun, R. (2014). An exploratory investigation of factors shaping electronic commerce practices in Iran: Benchmarking the role of technology and culture. Benchmarking: An International Journal, 21(5), 775-791. https://doi.org/10.1108/bij-12-2012-0086

[41] Macedo, I. M. (2017). Predicting the acceptance and use of information and communication technology by older adults: An empirical examination of the revised UTAUT2. Computers in Human Behavior, 75, 935-948. https://doi.org/10.1016/j.chb.2017.06.013

[42] Peek, S. T. M., Aarts, S., \& Wouters, E. J. M. (2017). Can smart home technology deliver on the promise of independent living? A critical reflection based on the perspectives of older adults. Handbook of Smart Homes, Health Care and Well-Being, 203-214. https://doi.org/10.1007/978-3-319-01583-5_41

[43] Peek, S. T. M., Wouters, E. J. M., van Hoof, J., Luijkx, K. G., Boeije, H. R., \& Vrijhoef, H. J. M. (2014). Factors influencing acceptance of technology for aging in place: a systematic review. International Journal of Medical Informatics, 83(4), 235-248. https://doi.org/ $\underline{10.1016 / j . i j m e d i n f .2014 .01 .004}$

[44] Petrovčič, A., Taipale, S., Rogelj, A., \& Dolničar, V. (2018). Design of mobile phones for older adults: An empirical analysis of design guidelines and checklists for feature phones and Smartphone. International Journal of Human-Computer Interaction, 34(3), 251-264. https://doi.org/10.1080/10447318.2017.1345142

[45] Phongtankuel, V., Shalev, A., Adelman, R. D., Dewald, R., Dignam, R., Baughn, R., ... Reid, M. C. (2018). Mobile Health Technology Is Here-But Are Hospice Informal Caregivers Receptive? American Journal of Hospice and Palliative Medicine $\AA$, 1049909118779018. https://doi.org/10.1177/1049909118779018

[46] Poushter, J. (2016). Smartphone ownership and internet usage continues to climb in emerging economies. Pew Research Center, 22.

[47] Rainie, L., \& Fox, S. (2012). Just-in-time information through mobile connections. Pew Internet \& American Life Project, 1-13.

[48] Rhema, A. (2013). An analysis of experiences and perceptions of technology-based learning in higher education institutions in Libya: informing the advancement of e-learning. Victoria University.

[49] Rogers, E. M. (1995). Lessons for guidelines from the diffusion of innovations. The Joint Commission Journal on Quality Improvement, 21(7), 324-328. https://doi.org/10.1016/ s1070-3241(16)30155-9

[50] Saare, Murtaja Ali; Jasim, Osamah Mohammed; Mahdi, Alia Ahmed; Hussain, A. (2018). Using Big Data in Healthcare Context: a Conceptual Study. International Journal of Engineering \& Technology, 7(20), 882-886. https://doi.org/10.14419/ijet.v7i3.20.28410

[51] Saare, M. A., \& Hussain, A. (2018). Successful Aging among Older Adults Using Computers: a Systematic Review. International Journal of Engineering \& Technology, 7(20), 50-54. https://doi.org/10.14419/ijet.v7i3.20.18730

[52] Saare, M. A., Hussain, A., \& Yue, W. S. (2019). Investigating the Effectiveness of Mobile Peer Support to Enhance the Quality of Life of Older Adults: A Systematic Literature Review. International Journal of Interactive Mobile Technologies, 13(4). https://doi.org/10. 3991/ijim.v13i04.10525

[53] Saare, M. A., Ta'a, A. B., Lashari, S. A., \& Sari, S. A. (2018). Mobile System for Managing and Mitigating the Accommodation Problems. In Journal of Physics: Conference Se- 
ries (Vol. 1019, p. 12045). IOP Publishing. https://doi.org/10.1088/1742-6596/1019/1/ $\underline{012045}$

[54] Saare, M. A., Ta, A. B., Lashari, S. A., \& Sari, S. A. (2018). Mobile System for Managing and Mitigating the Accommodation Problems.

[55] Smith, A. (2014). Older adults and technology use. Pew Research Center [Internet \& American Life Project].

[56] Steele, R., Lo, A., Secombe, C., \& Wong, Y. K. (2009). Elderly persons' perception and acceptance of using wireless sensor networks to assist healthcare. International Journal of Medical Informatics, 78(12), 788-801. https://doi.org/10.1016/j.ijmedinf.2009.08.001

[57] Steggell, C. D., Hooker, K., Bowman, S., Choun, S., \& Kim, S. J. (2010). The role of technology for healthy aging among Korean and Hispanic women in the United States: a pilot study. Gerontechnology, 9(4), 433-449. https://doi.org/10.4017/gt.2010.09.04.007.00

[58] Stellefson, M., Paige, S. R., Tennant, B., Alber, J. M., Chaney, B. H., Chaney, D., \& Grossman, S. (2017). Reliability and Validity of the Telephone-Based eHealth Literacy Scale among Older Adults: Cross-Sectional Survey. Journal of Medical Internet Research, 19(10). https://doi.org/10.2196/jmir.8481

[59] Suki, N. M. (2011). Gender, Age, and Education: Do They Really Moderate Online Music Acceptance? Communications of the IBIMA. https://doi.org/10.5171/2011.959384

[60] Tams, S., Grover, V., \& Thatcher, J. (2014). Modern information technology in an old workforce: Toward a strategic research agenda. Journal of Strategic Information Systems, 23(4), 284-304. https://doi.org/10.1016/j.jsis.2014.10.001

[61] Tarhini, A., Hone, K., Liu, X., \& Tarhini, T. (2017). Examining the moderating effect of individual-level cultural values on users' acceptance of E-learning in developing countries: a structural equation modeling of an extended technology acceptance model. Interactive Learning Environments, 25(3), 306-328. https://doi.org/10.1080/10494820.2015.1122635

[62] Teo, T., \& Milutinovic, V. (2015). Modelling the intention to use technology for teaching mathematics among pre-service teachers in Serbia. Australasian Journal of Educational Technology, 31(4). https://doi.org/10.14742/ajet.1668

[63] Thompson, R. L., Higgins, C. A., \& Howell, J. M. (1991). Personal computing: toward a conceptual model of utilization. MIS Quarterly, 125-143. https://doi.org/10.2307/249443

[64] Tsai, H. S., Shillair, R., \& Cotten, S. R. (2017). Social Support and "Playing Around" An Examination of How Older Adults Acquire Digital Literacy With Tablet Computers. Journal of Applied Gerontology, 36(1), 29-55. https://doi.org/10.1177/0733464815609440

[65] van Hoof, J., Kort, H. S. M., Rutten, P. G. S., \& Duijnstee, M. S. H. (2011). Ageing-inplace with the use of ambient intelligence technology: Perspectives of older users. International Journal of Medical Informatics, 80(5), 310-331. https://doi.org/10.1016/j.ijmedinf. 2011.02.010

[66] Venkatesh, V., Morris, M. G., Davis, G. B., \& Davis, F. D. (2003). User acceptance of information technology: Toward a unified view. MIS Quarterly, 425-478. https://doi.org/10. 2307/30036540

[67] Venkatesh, V., Thong, J. Y. L., \& Xu, X. (2012). Consumer acceptance and use of information technology: extending the unified theory of acceptance and use of technology. https://doi.org/10.2307/41410412

[68] Vesel, L., Hipgrave, D., Dowden, J., \& Kariuki, W. (2015). Application of mHealth to improve service delivery and health outcomes: Opportunities and challenges. African Population Studies, 29(1), 1683-1698. https://doi.org/10.11564/29-1-718

[69] Wilson, C., Hargreaves, T., \& Hauxwell-Baldwin, R. (2015). Smart homes and their users: a systematic analysis and key challenges. Personal and Ubiquitous Computing, 19(2), 463476. https://doi.org/10.1007/s00779-014-0813-0 
[70] Young, K. L., Koppel, S., \& Charlton, J. L. (2016). Toward best practice in human machine interface design for older drivers: a review of current design guidelines. Accident Analysis \& Prevention. https://doi.org/10.1016/j.aap.2016.06.010

[71] Zhao, Y., Ni, Q., \& Zhou, R. (2017). What factors influence the mobile health service adoption? A meta-analysis and the moderating role of age. International Journal of Information Management https://doi.org/10.1016/j.ijinfomgt.2017.08.006

\section{Authors}

Murtaja Ali Saare is a Ph.D. student at School of Computing, Sintok, Universiti Utara Malaysia, Kedah, Malaysia. He holds a master's degree in computer science. His research interests include aging and cognition, e-health, and human-computer interaction. He has published his work in reputable Scopus indexed journals.

Azham Hussain is the Associate Professor of Software Engineering at School of Computing, Universiti Utara Malaysia, Kedah, Malaysia. He is the founder of $\mathrm{Hu}-$ man-Centered Computing Research Group, which is affiliated with the Software Technology Research Platform Center at School of Computing, Universiti Utara Malaysia. Azham Hussain is a member of the US-based Institute of Electrical and Electronic Engineers (IEEE), and actively involved in both IEEE Communications and IEEE Computer societies.

Dr Wong Seng Yue is a senior lecturer at the Centre for the Initiation of Talent \& Industrial Training, Universiti Malaya, Kuala Lumpur, Malaysia. He received PhD degree in information science. He current researches include mobile augmented reality in STEM, gamification and e-health with industry 4.0.

Article submitted 2019-06-12. Resubmitted 2019-07-17. Final acceptance 2019-07-22. Final version published as submitted by the authors. 